\title{
Cross-Border Trading in Shares or Participations in Spanish Collective Investment Institutions: New Regime for Accreditation of Residence and Provision of Information
}

\author{
Dr. Luis Alfonso Martínez Giner, Tax Law Professor, University of Alicante
}

\section{Introduction}

In recent years, collective investment institutions (CIIs) have acquired legal importance and at the same time become popular among investors who appreciate diversification of their investment profile in terms of the risk involved and profitability of these financial instruments. ${ }^{1}$

One of the main concerns of CIIs making crossborder investments has been the question of application of the benefits derived from double taxation treaties to such institutions, since they do not fulfil the requirements necessary to be considered a person, resident or effective beneficiary. These concerns have long been analysed by international organizations. Both the $\mathrm{OECD}^{2}$ and the IFA (International Fiscal Association $)^{3}$ have made and continue to make efforts to eliminate the barriers that prevent the effective guarantee of treaty benefits in cases of investments made through collective investment institutions or funds. Not in vain, the value of assets managed by collective investment funds, according to the OECD itself, amounts to USD16 trillion, a large portion of which corresponds to cross-border portfolio investments.

In addition to these concerns, the practical implementation of cross-border trading of shares and participations in CIIs gives rise to certain problems that, should they remain unsolved, could well mean the failure of this type of investment. In this respect, one of the most important innovations that Spanish legislation has incorporated into the regulation of the legal system, in general, and the tax system, in particular, for collective investment institutions refers to the question of cross-border trading of shares or participa- tions in CIIs through foreign trading entities situated in another state.

This innovation is intended to solve the problems arising under the previous legislation making it difficult to carry out this activity, since it did not allow the use of 'global accounts' in which only the trading entity is identified, but required all the foreign investors to submit certificates accrediting their residence on a yearly basis. This was a serious obstacle, both financial and fiscal, that made it very difficult to use foreign trading entities.

However, the importance of cross-border trading and the need to allow Spanish CIIs to operate in the European Union made the change in legislation unavoidable. As is well-known, collective investment generates considerable savings or economies of scale, with the result that CIIs that attract savings in a greater number of states are more likely to survive in a competitive environment than those who do so in one state only.

Therefore, Spanish legislation has eliminated the main obstacles to cross-border trading of Spanish CIIs. Such obstacles were, as mentioned above, the prohibition of global accounts when registering the shareholders or participants in the CII, together with the obligation of each foreign investor to accredit his status as a non-resident. An added problem was that, in certain cases, the foreign trading entity was obliged to submit data on its clients to the CII's management company, which generally belonged to a competing financial group.

The new legal system mentioned above has two aspects that must be analysed in tandem: the commercial and the fiscal. The latter interests us most and centres on regulation of the new regime for

\section{Notes}

G.A. Giannantonio, 'Cross-Border tax issues of collective investment Institutions and the Italian approach', Intertax, vol. 33, no. 12 , p. 614.

In 1977 the OECD published The taxation of collective investment institutions, and in 1999 The taxation of cross-border portfolio investment, mutual funds and possible tax distortions. In addition, in February 2006, more than 115 participants representing 29 countries and tax experts from the financial sector discussed in Paris - in an event organized by the OECD Centre for Tax Policy and Administration with the assistance of the BIAC (Business and Industry Advisory Committee) - the application of double taxation treaties to collective investment institutions.

Several IFA Congresses have focused on this question. In 1962, in Athens, it was agreed that the tax situation of participants in collective investment institutions whatever their legal status - should be the same as if they held the shares directly, taking into consideration a sufficient guarantee against any possible abuses ('Fiscal problems arising in connection with investment trusts of international character', in Cahiers de droit fiscal international, 1962, vol. 47b). Also, in the 25th Congress of IFA held in Washington in 1971 it was declared that use of an Investment Trust (IT) should not affect the amount of tax levied on income derived from the investment, with only the capital gains realized by the IT being taxed at the level of the shareholders, whereas the capital gains not distributed by the IT are not considered. ('The fiscal treatment of international investment trusts and mutual funds, having regard to the major regulatory and foreign exchange features in the various countries', Cahiers de droit fiscal international, vol. 56 a , General Report Dr. Kurt Amonn). Finally, the 51st Congress of IFA held in New Delhi in 1997 dealt with the taxation of international funds. The General Report submitted by Lynne J. Ed and Dr. Bongaarts maintains that CIIs need to be able to avail themselves of the tax treaty benefits so as to prevent an excessive tax burden in the chain between investor and investment when a fund is involved. ('The taxation of funds', Cahiers de droit fiscal international, vol. 82b). 
accreditation of residence in cases of cross-border trading of shares or participations in CIIs abroad, and the obligation of the foreign trading entity to provide information to both the Spanish CIIs and the Spanish tax authorities.

The legal origin of this question is found in Directive 85/611 of 20 December 1985 on the coordination of laws, regulations and administrative provisions relating to undertakings for collective investment in transferable securities (UCITS Directive). ${ }^{4}$ This rule introduces the need to coordinate and align the conditions in which collective investment institutions compete so as to facilitate the trading of their shares or participations in other Member States. ${ }^{5}$ At the same time, in accordance with the Directive it is necessary to eliminate restrictions on the free movement of shares and participations in collective investment institutions in the European Union. This should not mean a limitation of the investors' rights, and an essential requirement is that the collective investment institution, investors and even the tax authorities have all the necessary information. With this in mind, Art. VIII of the Directive regulates trading of participations by collective investment institutions in Member States other than those in which they are located.

This Directive centres on the complicated task of constructing and regulating a European capital market in which harmonized rules integrate the capital markets of the different Member States. ${ }^{6}$ This harmonization may be said to have commenced in 1979 with Council Directive 79/279/EEC of 5 March coordinating the conditions for the admission of securities to official stock exchange listing, although the first step could be considered to be the Commission Recommendation for a European Code of Conduct relating to transactions in Transferable Securities in 1977.7

The provisions of Directive $85 / 611$ have been transposed into Spanish law recently. First, s. 16 of the Collective Investment Institutions Act 35/2003 of 4 November ${ }^{8}$ regulates the trading of shares and participations in Spanish CIIs within the European Union. It lays down that the requisites of Directive 85/ 611 must be fulfilled and a certificate authorizing such trading issued by the Spanish commercial authorities is compulsory. However, it is the Regulation ${ }^{9}$ implementing Act 35/2003 that regulates in detail the requisites, conditions and legal system for cross-border trading in shares and participations in Spanish CIIs. Moreover, this Regulation incorporates an additional provision in the Non-Residents' Income Tax Regulation ${ }^{10}$ which sets out in general terms the rules which, for tax purposes, regulate the relation between the CIIs and the foreign trading company, together with the relation between the latter and the Spanish tax authorities as regards application of the Non-Residents' Income Tax Act or the relevant double tax treaties.

Finally, Ministerial Order 1674/2006 of 24 May of the Ministry of Economics and Finance specifies the different essential aspects, from the tax point of view, which had previously hindered cross-border trading of CIIs. In particular, this Order provides a special procedure for accreditation of residence of certain non-resident shareholders or participants in operations relating to cross-border trading of shares or participations in CIIs, together with all the obligations concerning provision of information to Spanish tax authorities or the CIIs themselves.

The following analysis is focused on the fiscal aspects of this type of cross-border trading of shares or participations in CIIs. It examines the new regime for accreditation of residence and the resulting obligation to provide information in more detail. However, it is necessary to make a brief reference to certain commercial aspects in order to understand how this type of CII operation functions and thus achieve a better understanding of the fiscal aspects.

\section{Commercial aspects}

Spanish CIIs may trade their shares or participations within the European Union bearing in mind the provisions of Directive 85/611. First, it should be pointed out that any collective investment institution that wishes to trade its participations in another Member State must abide by the laws, regulations and administrative provisions in force in that state. ${ }^{11}$ Furthermore, the collective investment institution must take the measures necessary to ensure that facilities are available in that state for making payments to investors, re-purchasing or redeeming of units and making available the information such institutions are

\section{Notes}

OJ, L 375, 31 December 1985. This Directive was amended by the following: Directive 88/220/EEC of 22 March 1988; Directive 95/26 of 29 June 1995; Directive 2000/64 of 7 November 2000; Directive 2001/107 of 21 January 2002; Directive 2001/108 of 21 January 2002; Directive 2004/39 of 21 April 2004.

5 This Directive is a specific example of a non-systematic approximation of different aspects of the harmonization of contract law and in response to specific problems attempts to focus on the integration of financial markets. (A. Sainz de vicuña, 'The legal integration of financial markets', European Business Law Review, September-October 2003, p. 230).

6 Niamh Moloney, 'New frontiers in EC Capital Markets law: from market construction to market regulation', in Common Market Law Review 2003, vol. 40, p. 809 .

G. Ferrarini, 'The European regulation of stocks exchanges: new perspectives', Common Market Law Review 1999, vol. 36, pp. 569-598.

OJ, 5 November 2003.

9 Royal Decree 1309/2005 of 4 November, passing the Regulation of the Collective Investment Institutions Act 35/2003 and adapting the tax regime of collective investment institutions.

10 Royal Decree 1776/2004 of 30 July.

11 Article 44.1 of Directive $85 / 611$. 
obliged to provide to unit-holders. ${ }^{12}$ Likewise, it is necessary to provide the authorities of the Member State in which the collective investment institution proposes to trade its units with a smooth flow of information. ${ }^{13}$ Once these steps have been taken, the institution may commence the trading of its units in the other state, unless the authorities have reason to believe that the requisites and conditions enabling cross-border trading of the shares or participations in such institutions are not fulfilled.

Such activity can only be carried on in other Member States through entities legally authorized by these states to trade with collective investment institutions situated in other Member States. ${ }^{14}$ The main innovation incorporated in the Spanish legal system is the possibility of registering the cross-border trading of shares or participations in collective investment institutions in global accounts in the name of intermediary entities resident abroad, bearing in mind that the shareholders or participants that operate through the trading entity should figure in the latter's name. ${ }^{15}$

In practice this system will mean that not only is the foreign trading entity the link between foreign investors and the collective investment institution but it also plays an essential role in fulfilling the relevant obligations and ensuring the system functions correctly. Thus, the foreign trading entity must inform the Spanish collective investment institution of the balance of subscriptions and reimbursements or transfers made, as well as make or request payment of this balance. In addition, periodically at the time agreed for subscription and reimbursement of participations or the acquisition and transfer of shares, the foreign intermediary will communicate the number of shareholders or participants operating through it.

The importance of foreign trading entities in the cross-border trading of collective investment institutions lies in the fact that they are the organisms that channel the information to and from the foreign participants or shareholders. Thus, in cross-border trading it is the foreign intermediary that is obliged to fulfil certain obligations concerning the provision of information both to shareholders or participants operating through it and to the Spanish supervisory authorities. ${ }^{16}$ A logical result of application of the system is that Spanish residents cannot be shareholders or participants in CIIs through foreign trading entities.

The validity of this type of cross-border trading contract as far as the CIIs are concerned is conditioned by the trading company fulfilling its obligations. The contract is invalidated the moment the collective investment institution becomes aware that any obligation has not been fulfilled. ${ }^{17}$ In other words, the contract is automatically discharged due to the trading entity's non-fulfilment of the conditions and obligations.

\section{Fiscal aspects}

\section{A. General considerations}

From the tax point of view, once the purely commercial aspects of this legal figure have been analysed, the importance of the accreditation of residence of the subjects receiving income from a Spanish CII should be mentioned, together with the information mechanisms that are necessary for correct application of the Spanish tax rule and the various double taxation treaties entered into between Spain and other states.

In this respect, it should be borne in mind that the income obtained by clients of foreign trading entities from shares or participations in Spanish CIIs may be classified in two ways: first, it may take the form of profits distributed by Spanish CIIs among foreign investors, and secondly, there may be reimbursement of participations or transfer of shares of the Spanish CII, which are legally considered capital gains. Under Spanish law, such earnings are considered to be obtained in Spain. ${ }^{18}$

Withholdings at a rate of 15 per cent are made on these earnings obtained by non-residents from Spanish CIIs in the case of both distributed profits ${ }^{19}$ and capital

\section{Notes}

12 Article 45 of Directive 85/611.

13 Article 46 of Directive 85/611. The collective investment institution is obliged to send a series of documents to the authorities of the Member State in which it proposes to trade its units: first, a certificate accrediting that this collective investment institution fulfils the conditions imposed by the Directive; secondly, its fund rules or instruments of incorporation; thirdly, the complete and simplified versions of its prospectus; fourthly, its latest annual report and any subsequent halfyearly report; finally, a description of the arrangements made for the trading of its units in that other Member State.

14 Article 20.2 of Royal Decree 1309/2005 of 4 November. In any case, the collective investment institution's management company is not exempt from responsibility for the activities carried on by the trading entity.

15 Article 20.2(a) of Royal Decree 1309/2005, of 4 November.

16 It is provided that the trading entities are obliged to make available to the foreign investors operating through them the informative documents that under the applicable legislation the latter are entitled to receive. Likewise, these entities must send to the Spanish National Commission for the Securities Market all the information relating to the shareholders and participants operating through them that the collective investment institution itself is obliged to send to this supervisory authority. If this trading entity were not to fulfil its obligation to provide information, the Spanish collective investment institution would automatically be considered responsible by the Spanish authorities, for whom the cross-border trading contract would immediately be deemed lacking in validity.

17 Article 20.2(e) of Royal Decree 1309/2005 of 4 November.

18 The Non-Residents' Income Tax Act passed by Legislative Royal Decree 5/2004 of 5 March sets out in s. 13 the criteria for certain income to be considered obtained in Spain, and therefore subject to the Spanish Non-Residents' Income Tax Act. Thus, s. 13(1)(f)(1) provides: 'Dividends and other earnings derived from participation in the funds of entities resident in Spain are considered obtained in Spain'. Regarding capital gains, s. 13(1)(i) stipulates the following: 'Capital gains derived from securities issued by persons or entities resident in Spanish territory are considered obtained in Spain'.

19 Section $25(1)(\mathrm{g}) 1$ of the Non-Resident's Income Tax Act. 
gains. ${ }^{20}$ However, certain income, specifically certain capital gains, may be declared exempt, as laid down in s. 14(1)(c) and (i) of the Non-Residents' Income Tax Act. The former regulates the generic exemption of capital gains derived from movable property obtained by residents of another Member State of the European Union without a permanent establishment. ${ }^{21}$ On the other hand, s. 14(1)(i) of the Non-Resident's Income Tax Act provides that when the Spanish legislation is applicable, income derived from the transfer of securities or reimbursement of participations in investment funds made on an official secondary Spanish securities market ${ }^{22}$ obtained by non-resident natural persons or entities without a permanent establishment in Spanish territory, who are residents of a state with which Spain has signed a treaty to avoid double international taxation that contains an exchange of information clause, ${ }^{23}$ are exempt and therefore not taxed in Spain. This exemption is subjectively broader than the generic exemption of 'European' capital gains, since it is not limited to territory of the European Union but applicable to income obtained by any resident in any country that has entered into a double taxation treaty with Spain, although objectively it is limited to earnings derived from the transfer or reimbursement of shares or participations in investment funds.

Furthermore, it should be pointed out that when a treaty to avoid double taxation is applicable, it may be possible to apply a lower rate of tax than the 15 per cent envisaged in the domestic Spanish legislation to the income obtained by foreign investors in Spanish CIIs derived from the distribution of profits. In such cases, the tax rate envisaged in the double taxation treaty is applied. In practice most of the double taxation treaties lay down a maximum tax rate of 15 per cent in the case of benefits distributed by entities resident in Spain to non-resident natural persons acting without a permanent establishment. Only in certain specific cases do the treaties specify a maximum tax rate of 10 per cent. ${ }^{24}$ If the beneficiary of the distribution of profits is a foreign corporation, the maximum tax rate established in the treaty is still, in general terms, 15 per cent. However, many tax treaties apply a tax rate of 10 per cent when the non-resident company owns at least 25 per cent of the capital of the company that distributes the profits. ${ }^{25}$

In addition, application of a double taxation treaty may, in the case of capital gains, result in taxation only in the state of residence of the alienator of shares or participations in the Spanish CII, pursuant to Art. 13.5 of the OECD Model Convention, with the exceptions set out in the previous paragraphs of this article.

In view of all this, the correct accreditation of residence would seem to be of unquestionable importance, both for withholdings to be made at source at limited rates and for the corresponding exemption to be considered applicable pursuant to the treaty or domestic law. Therefore, the additional provision of the Non-Residents' Income Tax Regulation passed by Royal Decree 1776/2004 of 30 July provides in para. 3 that the Ministry of Economics and Finance will determine the content of the residence certificates in cases of cross-border trading of shares and participations in Spanish CIIs, the details to be included, and the periods within which the foreign trading entity must submit the information to the management company of the Spanish CII or the Spanish tax authorities in the CII's name.

In order to facilitate application of the Spanish tax rule, the Ministry of Economics and Finance in its Ministerial Order 1674/2006 of 24 May $^{26}$ regulates the special procedure for accreditation of residence and obligation to provide the information necessary to allow withholdings to be made.

\section{B. Regime for accreditation of residence}

As laid down in the statement of reasons of Ministerial Order 1674/2006 of the Department of Taxation and Finance, this special procedure for accrediting residence is established for two purposes: first, to justify making withholdings, when the maximum tax rate fixed in the treaty is applied, or not making withholdings as a result of application of a treaty or domestic rule provided that the non-resident taxpayer is resident in the same country as the trading entity and Spain has signed with this country a treaty to avoid double taxation containing an exchange of informa-

\section{Notes}

20 Section 25(1)(g)3 of the Non-Resident's Income Tax Act.

21 An exception to this exemption is provided: capital gains derived from the transfer of shares or participations in an entity whose assets, directly or indirectly, consist mainly of unmoveable property situated in Spanish territory are not exempt. Nor does the exemption apply when within the twelve months prior to the transfer the taxpayer participated, directly or indirectly, in at least 25 per cent capital of this entity.

22 It is considered wrong to demand this requisite in the case of investment funds since they are not quoted on a stock exchange, an intrinsic characteristic of how they operate being that the liquidity of participations is guaranteed by means of direct reimbursement (J.C. Caño Alonso, Tributación de las instituciones de inversión colectiva y de sus accionistas o partícipes (Aranzadi, Pamplona, 2004), p. 287).

23 All the double taxation treaties signed by Spain contain an exchange of information clause except the treaty with Switzerland. Spain has signed treaties with the following countries: Algeria, Argentina, Australia, Austria, Belgium, Bolivia, Brazil, Bulgaria, Canada, Korea, Czechoslovakia (Czech Republic and Slovakia), Chile, China, Croatia Cuba, Denmark, Ecuador, Egypt, Slovenia, US, Estonia, Philippines, Finland, France, Germany Greece, Hungary, India, Indonesia, Ireland, Iceland, Israel, Italy, Japan, Estonia, Lithuania, Luxembourg, Macedonia, Malta, Morocco, Mexico, Norway, Netherlands, Poland, Portugal, United Kingdom, Romania, Russia, Sweden, Switzerland, Thailand, Tunis, Turkey, Venezuela and Vietnam.

24 An example of this 10 per cent tax rate is found in the treaties between Spain and Brazil, Chile, China, Greece, Israel, Thailand and Venezuela.

25 This is the case of Finland, Greece, Iceland, Turkey and Bolivia.

26 OJ, 1 June 2006. 
tion clause. Secondly, by means of this procedure the trading entity accredits to the withholder that the income obtained by all its clients is subject to nonresidents' income tax.

As the additional provision of the non-residents' income tax regulation points out, when benefits are distributed by the institution or reimbursements or transfers of its participations or shares take place, the trading entity is obliged to send to the management company or investment company certificates of residence of its clients, beneficiaries or transferors, as stipulated by the Department of Taxation and Finance. In accordance with the rule, a global certificate of fiscal residence, which does not identify the individual taxpayers, issued by the foreign trading entity must be sent to the management company of the Spanish investment company or fund when profits are distributed or reimbursements or transfers of participations or shares in the collective investment institutions are made, and this is accepted as a document accrediting fiscal residence.

To achieve this, it is necessary to amend the regulatory rules that specify the accreditation documentation necessary for withholdings to be made. This must be coherent with the global account system by which the foreign trading entities and not the taxpayers figure as beneficiaries of the distributed profits or transferors of shares or participations in the Spanish CII.

Thus, the rules regulating the forms to be used (types of tax returns and the form for depositing withholdings made on certain income subject to nonresidents' income tax obtained by taxpayers without a permanent establishment) are amended. ${ }^{27}$ In the case of cross-border trading of shares or participations in Spanish CIIs by means of global accounts in the name of foreign trading entities, a special procedure for accreditation of residence is established in order to make withholdings on the profits distributed by Spanish CIIs. This accreditation of residence involves the foreign trading entity sending to the Spanish CIIs a certificate for each CII or each type of participation or series of shares of the CII whenever profits are distributed. This certificate must contain the following information:

- place and date of issue of the certificate;

- identification of the trading entity, tax identification number allocated by the Spanish authorities and address in the country of residence;

- identification and position of the duly authorized person signing the certificate;

- identification of the CII, tax identification number allocated by the Spanish authorities and fiscal residence;

- denomination, where appropriate, of the type or class of participations or series of shares;
- ISIN (International Securities Identification Numbering system) code of the participations or shares in the CII;

- identification of any Spanish management company of the CIIS;

- date of distribution of profits;

- number of beneficiaries resident, within the meaning of the treaty, in the same country as the trading entity and the total amount of profits received;

- if there is a double taxation treaty, the number of other beneficiaries not resident in the same country as the trading entity and the total amount of profits distributed.

With this certificate the Spanish CII may justify the withholdings made, either at the maximum tax rate established in the treaty for residents in the same country as the trading entity or the rate laid down in Spanish legislation for distributed profits in the case of the other beneficiaries.

In addition to this non-specific generic certificate, the foreign trading entity must send to the Spanish CII its own certificate of fiscal residence, issued by the tax authorities in its country, which is valid for three years after its date of issue.

This certificate must be sent to the Spanish CII in the first ten days of the calendar month after the month in which the profits are distributed and, under s. 70 of the General Tax Act, the CII is obliged to conserve this document for the prescription period of four years.

When the CII submits its annual withholding tax return, for each distribution of profits, it will group together the information relating to the group of beneficiaries included on the certificate remitted by the trading entity and distinguish between taxpayers who have borne a withholding tax rate lower than that laid down in the Spanish tax rule - as a result of application of the treaty - and the rest. In all cases, the trading entity figures as the beneficiary. This procedure must be understood to be applicable subject to the possibility that the tax authorities may require any taxpayer to justify his right to apply the treaty.

Likewise, in the case of capital gains generated as a result of the transfer or reimbursement of shares or participations in the CIIS by foreign investors through foreign trading entities, a similar procedure for accreditation of residence is established for the purpose of making withholdings on such gains obtained by non-residents' income tax payers without a permanent establishment. ${ }^{28}$

The system of accreditation differs slightly depending on whether the trading entity resides in a country with which Spain has signed a double taxation treaty containing an exchange of information clause or not. In the first case, whenever the CII makes reimbursements or transfers, the trading entity must send to the

\section{Notes}

27 Specifically, concerning the distribution of profits Order of 9 December 1999 adopting form 216 and the annual summary, form 296 is amended.

28 Specifically, Order of 15 December 1999 adopting form 187 is amended. 
Spanish CII a certificate containing the following information:

- place and date of issue of the certificate;

- identification of the trading entity, tax identification number allocated by the Spanish authorities and address in its country of residence;

- identification of and position held by the duly authorized person signing the certificate;

- identification of the CII, tax identification number allocated by the Spanish authorities and fiscal residence;

- denomination, where appropriate, of the type or class of participations or series of shares;

- ISIN (International Securities Identification Numbering system) code of the participations or shares in the CII;

- identification of any Spanish management company of the CII;

- regarding investors resident in the same country as the foreign trading entity to whom an exemption may be applied pursuant to a treaty or domestic rule:

- number of transferors resident in the same country as the trading entity who obtained capital gains and are entitled to an exemption,

- number of participations or shares reimbursed or transferred,

- total amount of reimbursements or transfers,

- total purchase price corresponding to these reimbursements or transfers;

- regarding the other taxpayers:

- number of transferors that obtained capital gains,

- number of participations or shares reimbursed or transferred,

- total amount of reimbursements or transfers,

- total purchase price corresponding to these reimbursements or transfers,

- total amount of capital gains.

With this certificate, the management company of the Spanish CII may justify either exemption of the capital gains obtained by the non-resident pursuant to the treaty or domestic rule, or the withholding made on such gains. Apart from this generic certificate, the foreign trading entity must send to the Spanish CII its own fiscal residence certificate issued by the tax authorities of its country, which will be valid for three years as of its date of issue.

If the trading entity does not reside in a country with which Spain has signed a double taxation treaty containing an exchange of information clause, the foreign trading entity must send to the Spanish CII the same certificate as that envisaged in the case of taxpayers resident in a different country to that in which the trading entity is located.
Regarding the time when such certificates must be sent and the obligation to conserve them throughout the prescription period provided in Spanish law, the same formal determining factors envisaged for the case of distribution of profits are applied.

In summary, a special procedure for accreditation of residence is regulated in which the essential element is the foreign trading entity, which in a global way figures as the beneficiary of the profits or as the member or participant that obtains the gains. This entity must accredit its own residence and send to the Spanish CII monthly certificates with global information concerning the number of clients receiving the profits or obtaining the gains, together with the global amount thereof.

In all cases, as provided in the additional provision of the Non-Residents' Income Tax Regulation, if the trading entity does not fulfil any of its obligations as regards sending the above-mentioned certificates, accreditation of the identity of non-resident investors and their tax residence shall be carried out in accordance with the provisions of the Non-Residents' Income Tax Act and its rules of implementation. ${ }^{29}$

Finally, this system requires trading entities resident abroad to fulfil the obligation to provide information to the Spanish tax authorities.

\section{Obligation to provide information}

The second pillar on which this system of accreditation of residence rests in the case of cross-border trading of shares and participations in CIIs concerns the relation between the trading entity and the Spanish tax authorities. Thus, the Non-Residents' Income Tax Regulation provides that the former is obliged to send to the latter, on behalf of the Spanish CII, a detailed list of the participants or shareholders, beneficiaries or transferors, together with a detailed annual list of its clients with their investment situation in the Spanish CII. Moreover, the foreign trading entity must inform the CII of the fulfilment of these obligations to provide information. ${ }^{30}$

To be specific, under Art. 3 of Order 1674/2006, the foreign trading entity basically has two obligations to provide information. First, every year it must send to the Spanish tax authorities a list of its clients who receive profits distributed by a Spanish CII, together with those in whose name reimbursement or transfer of shares or participations have been made. Secondly, each year a list of the clients of the foreign trading entity and their investment situation in the CII at 31 December of the previous year must be provided.

Both documents must be sent in the first three months of each calendar year in the form of

\section{Notes}

29 It should be noted, as pointed out by A. Ribes Ribes, 'La problemática de los certificados de residencia en el Impuesto sobre la Renta de los No residentes', in Quincena Fiscal, nos. 21-22, 2005, p. 14, that the Spanish legislation has no provision as to how fiscal residence may be accredited in another country. The Spanish tax authorities simply require justification in the form of certificates of residence and no other legal means or evidence is accepted as justification.

30 Additional provision of the NRIT regulation. 
computerized files in which, in addition to the usual details of the foreign trading company, and the Spanish CII, each client should be clearly identified and full details given of each receipt of profits or transfer or reimbursement of shares or participations. This information includes: date of distribution of profits or transfer or reimbursement and number of shares or participations reimbursed or transferred, gross amount received or amount of the transfer or reimbursement, as well as the purchase price of the shares or participations, and the amount of the withholdings made in Spain in euros.

In the case of the detailed list of clients and their investment situation in the CII, the electronic file must also include identification of the shares or participations that each investor owns, with its ISIN code, the number of shares or participations at 31 December, their purchase price and the market value of these shares or participations.

Once these requirements have been met, the foreign trading entity is obliged to inform the Spanish CII that it has fulfilled these obligations of providing information in the first three months of each calendar year. In this communication after identifying the sender (entity or person) it is necessary to provide the date each list was sent to the Spanish tax authorities, together with the electronic validation code provided by the latter.

\section{Final remarks}

Thanks to this regime for accreditation of residence, trading by Spanish CIIs abroad through global accounts is a reality that will make it possible to participate more actively in the European financial system and Single Market. Fiscal obstacles and problems arising when the necessary withholdings at source were made as a result of application of the Spanish tax rule are overcome with this system of accreditation of residence and provision of information.

Taxation of taxpayers who are not resident in Spain and have invested in Spanish CIIs through foreign trading entities is assured, or at least may be justified by means of the system of accreditation of residence analysed above. Above and beyond other considerations, what can be underlined is that the intention was to provide a simple, agile regulation of this procedure for accreditation of residence which combines legality with the possibility of a foreign trading entity being considered the beneficiary of the profits or transfers or reimbursements, while it is understood that the final beneficiary of the income is a subject known to the Spanish tax authorities, who receive in the first three months of each year a detailed list of all recipients of earnings. Throughout the process, the non-resident taxpayers' rights are protected since the information that the foreign trading entity provides to the Spanish tax authorities is simply a reflection of the transactions that have taken place in the source state and are understood to have been carried on with the foreign trading entity.

A truly European financial market requires that tax rules not be an obstacle to the free movement of capital. In this respect, cross-border trading of shares or participations in CIIs is one step further in this direction. A desired objective should be to facilitate application of tax rules by Member States in the most neutral and specific way possible. 